- М. : Знание, 1979. - 47 с. 9. Табачек І. В. Формування та розвиток особистості сучасного вчителя: дис. ... канд. філософ. наук: 09.00.10 / І. В. Табачек. - К., 2005. - 173 с.

УДК 372: 37.035

Н. В. Рогальська,

кандидат пед. наук, доцент,

Уманський державний педагогічний

університет імені Павла Тичини

\title{
ВИКОРИСТАНННЯ МЕТОДУ ПРОЕКТІВ У ПРОФЕСІЙНІЙ ПІДГОТОВЦІ МАЙБУТНІХ ФАХІВЦІВ ДОШКІЛЬНОЇ ОСВІТИ
}

Рогальська Н. В. Використання методу проектів у професійній підготовці майбутніх фахівців дошкільної освіти.

У статті розглядається проблема удосконалення професійної підготовки майбутніх фахівців дошкільної освіти, зокрема йдеться про використання у навчально-виховному процесі вищих навчальних закладів методу проектів.

Ключові слова: інноваційні технології, професійна підготовка студентів, метод проектів, дошкільна освіта.

Рогальская Н. В. Использование метода проектов в профессиональной подготовке будущих специалистов дошкольного образования.

В статье рассматривается проблема усовершенствования профессиональной подготовки будущих специалистов дошкольного образования, в частности раскрывается проблема использования в учебно-воспитательном процессе высших учебных заведений метода проектов.

Ключевые слова: инновационные технологии, профессиональная подготовка, метод проектов, дошкольное образование.

Rogalskaya N. V. Using projects in the training of future specialists preschool education.

The paper addresses the problem of improving the professional training of preschool education specialists, in particular in use in the educational process of higher education project method.

Key words: innovative technology, training students, project method, pre-school education.

Розвиток суспільства в нашій державі перебуває в тісному взаємозв'язку з необхідністю розв'язання інноваційних реформ, серед яких значну роль відіграють реформи освіти. Новий етап розвитку суспільства істотно змінює наші уявлення про мету і цінності освіти, актуалізує проблеми полікультурного виховання, акцентує на соціальній активності, громадянськості та саморозвитку особистості. У Білій книзі національної освіти України наголошується, що «кадрове» питання $\epsilon$ одним 3 головних у забезпеченні якості дошкільної освіти. Із розбудовою демократичного суспільства в нашій державі динамічно почала змінюватися освітня парадигма, підходи до забезпечення освітніх потреб суспільства, однак кадровий супровід не завжди відповідає цим запитам. Базовий компонент дошкільної освіти в Україні проголосив модернізацію змісту дошкільної освіти, впровадження в практику особистісно зорієнтованих технологій, а підготовка майбутніх спеціалістів триває за застарілими методиками. Такий підхід до формування майбутніх педагогів-дошкільників не відповідає вимогам сучасності [1]. Відтак, створення єдиного освітнього простору в межах $Є C$, орієнтація України на інтеграцію в Європейський освітній простір гостро вимагають удосконалення професійної підготовки студентів до використання педагогічних інновацій у майбутній педагогічній діяльності.

Ці проблеми можна розв'язувати, використовуючи у професійній підготовці студентів сучасний ефективний метод проектів. Питанням використання проектних технологій у навчальному процесі присвячені численні дослідження В. Безпалька, I. Булах, Б. Гершунського, Р. Кларка, О. Пєхоти, Є. Полат. Натомість використання проектного методу у професійній підготовці майбутніх дошкільних педагогів залишилося недостатньо вивченим. 
Зазначимо, що інноваційні підходи до оптимізації професійного становлення особистості вихователя характеризуються різноманітністю творчого пошуку. Це розроблення і впровадження новітніх спецкурсів і спецсемінарів, творчих дослідницьких завдань і способів контролю, модульне навчання та рейтингова система оцінювання. Основні аспекти вдосконалення процесу фахової підготовки педагога на засадах формування готовності до інноваційної діяльності знайшли своє відображення у працях А. Алексюка, Л. Артемової, Г. Бєлєнької, А. Богуш, В. Бондаря, О. Козлової, К. Крутій, В. Кузя, І. Підласого та ін. Відтак, актуальності набуває проблема запровадження інноваційних технологій, зокрема проектного методу в навчально-виховний процес вищих навчальних закладів.

Mema cmammi - обгрунтувати основні аспекти використання методу проектів у підготовці майбутніх вихователів у навчально-виховному процесі вищих навчальних закладів, дослідити вплив використання методу проектів на розвиток професійних умінь студентів.

На наш погляд, навчально-виховний процес вищої школи надає змогу ефективно використовувати інноваційні педагогічні технології, сучасні засоби педагогічної комунікації тощо. Проте, спостереження зазвичай засвідчують лише декларування педагогами використання інноваційних технологій. На практиці інновації в діяльності викладачів використовуються стихійно та необгрунтовано. Зазначимо, що великою мірою це пояснюється суб'єктивними чинниками, зокрема, недостатньою освітньою, культурною, особистісною готовністю педагогів до запровадження інноваційних технологій у навчальновиховний процес освітньої установи.

На думку Н. Юсуфбекової, нині важливо теоретично осмислити інноваційні процеси в освіті, науково обгрунтувати їх, що забезпечить ефективне використання інноваційних технологій у практиці освітніх закладів [4]. Сучасні науковці [2; 3; 4] розглядають проблему формування інноваційної готовності студентів до майбутньої професійної діяльності як найбільш пріоритетну. Вищі навчальні заклади насамперед повинні забезпечити високий рівень професійних знань і вмінь студентів, сформувати творчу активність сучасного педагога, здатного до самовдосконалення, дослідницької та інноваційної діяльності.

Науковці стверджують, що запровадження в навчально-виховний процес вищої школи інноваційних педагогічних технологій створює умови для оновлення професійної підготовки майбутніх фахівців, забезпечує їх самодостатній розвиток i професійну інноваційну діяльність [2; 3; 4].

Технологія професійної підготовки майбутніх фахівців складається зі способів конструювання змісту навчання, адекватного завданням сучасності, ефективної системи теоретичних та практичних методів підготовки фахівців, різноманітних форм організації навчально-виховного процесу, взаємодії викладачів та студентів на основі особистісно зорієнтованої моделі.

Аналіз наукових досліджень А. Нісімчука, О. Падалка, I. Смолюка, О. Шпака переконують в тому, що характерними ознаками педагогічних технологій є процеси програмування, проектування, конструювання, моделювання, спрямовані на вдосконалення традиційного педагогічного процесу, на конкретний i гарантований педагогічний результат.

Відтак, підготовлений до інноваційної професійної діяльності педагог дошкільного навчального закладу повинен мати такі професійні уміння: уміння враховувати особливості дошкільного дитинства й специфіку функціонування дошкільних навчальних закладів у соціумі; уміння визначати нові освітні цілі, зміст, методи, форми організації навчально-виховної діяльності дошкільників; уміння реалізовувати особистісно зорієнтований підхід до дітей, творчо, продуктивно використовувати інноваційні технології задля їхнього розвитку, виховання і навчання; уміння організовувати взаємодію вихователя, дітей, батьків та громадськості на засадах партнерства та діалогу. 
Практика нашої діяльності засвідчує, що в удосконаленні підготовки майбутніх фахівців дошкільної освіти, формуванні їхньої інноваційної готовності велику роль відіграє метод проектів.

Зазначимо, що ідеї використання методу проекту в практиці викладання є не новацією, він був здобутком американських авторів гуманістичного спрямування в освіті Дж. Дьюї, У. Кілпатріка, які пропонували організувати активне цілеспрямоване навчання учнів, яке побудоване на особистісному інтересі й зацікавленні дітей. Нагадаємо, що на початку XX століття американський педагог Уільям Кілпатрік розробив особливий метод роботи 3 дітьми, що дозволяє індивідуалізувати роботу зі школярами і вибудовувати навчальний процес, ураховуючи їхні інтереси. Слово «проект», що в перекладі з латинської означає «кинутий уперед», розглядалося як процес і як результат діяльності людей. Ідея навчатися 3 використанням методу проекту набула поширення у вищих закладах освіти Свропи та США у ХХ столітті.

В основу методу проектів покладено ідею про сутність категорії «проект», іiі прагматичну спрямованість на результат, якого можна досягти під час розв'язання відповідної практичної чи теоретично значущої проблеми. Зазначимо, що метод проектів сприяе розвитку пізнавальних навичок студентів, формуванню їхніх умінь самостійно конструювати власні знання, орієнтуватись в інформаційному середовищі, розвиває критичне і творче креативне мислення. Метод проектів широко використовувався в 20-ті роки i в Росії. Утім, у нього були як прибічники, так i противники. Противники стверджували, що метод не забезпечує систематичності навчання, яке важко організувати і ще важче оцінювати. Тому поступово метод проектів перестали використовувати. Ті складні процеси, що відбуваються не лише в Україні, а й в усьому світі не можуть не позначитися на розв'язанні педагогічною наукою і практикою проблеми формування в підростаючого покоління соціального досвіду в нових умовах. Очевидно, важливо аналізувати різні педагогічні технології стосовно сучасних реалій виховання і навчання дітей та визначення того нового, що вони вносять у соціальну ситуацію розвитку дитини.

Актуальним у контексті використання методу проектів на сучасному етапі є підхід науковців до педагогічної технології як продуманої у всіх деталях моделі спільної педагогічної діяльності з проектування, організації та проведення навчального процесу 3 безумовним забезпеченням комфортних умов для вчителя й учня. Метод проектів грунтується на постулатах, дотримання яких допомагає досягти оптимального рівня формування готовності майбутнього вихователя до професійної діяльності. Зокрема, йдеться про такі твердження:

- проектна діяльність посилює мотивацію студентів до навчання, активізує пошук дидактичних підходів в організації педагогічного процесу в дошкільних навчальних закладах;

- створює умови для творчої реалізації суб'єктів освітнього процесу, розвиває уміння забезпечити особистісно зорієнтований підхід до дітей.

Використання методу проектів у дошкільній освіті як одного з методів інтерактивного навчання дітей дозволяє:

- значно підвищити самостійну активність дошкільників, розвивати їхнє креативне мислення, уміння самостійно за допомогою різноманітних засобів знаходити інформацію про предмет або явище, використовуючи згодом ці знання для створення нових об'єктів дійсності;

- метод проектів можна вважати механізмом забезпечення партнерства та співпраці, діалогу сім'ї та ДНЗ, оскільки батьки можуть стати не тільки джерелом інформації, реальної допомоги та підтримки дитини і педагога у процесі роботи над проектом, а й бути учасниками педагогічного процесу, збагатити свій педагогічний досвід та отримати задоволення від успіхів дитини; 
- проектна діяльність реалізується через професійну підготовку педагогів, просвітницьку роботу 3 батьками та вимагає створення предметно-розвивального середовища відповідно до вимог проекту;

- упровадження в освітній процес проектної технології сприяє розвитку творчої особистості як дитини, так і вихователя, що відповідає соціальному замовленню держави на сучасному етапі iї розвитку.

Метод проектів - це спосіб організації педагогічного процесу в ДНЗ, що грунтується на партнерській взаємодії дошкільних педагогів, вихованців і батьків, у спеціально створеному розвивальному середовищі, поетапна практична діяльність дорослих і дітей для реалізації особистісно зорієнтованого підходу.

Використання методу проектів надає змогу реалізувати особистісно зорієнтований підхід до спільної діяльності в системі взаємин «вихователь - дитина - батьки». Цей метод надає змогу дошкільному педагогу бути партнером, консультантом батьків і дітей, а всі разом діти і дорослі стають однодумцями, вчаться розуміти один одного, допомагати, набувати досвіду міжособистісних стосунків. Як стверджують практики ДНЗ, така форма співпраці забезпечує високу ефективність організації педагогічного процесу, помітно покращує взаємини як між батьками і педагогами, так і між дітьми i батьками. Тому важливо мотивувати набуття знань у процесі розгортання проектної діяльності, потрібних дошкільному педагогу для успішної майбутньої професійної діяльності. Очевидно, що викладач має спрямувати студентів для самостійного виконання завдань проекту. Відтак, метод проектів - це спосіб організації навчально-виховного процесу, що грунтується на взаємодії викладача і студентів. Технологія проектування використовується нами як у формі індивідуальних науково-дослідницьких завдань, так і під час семінарів та практичних занять.

Зорієнтовані на спільну діяльність учасників освітнього процесу у ВНЗ проекти організовуються в різних варіантах: як спільна діяльність викладача і студентів над проектом; як спільна діяльність групи студентів над розробкою проекту; як виконання індивідуального науково-дослідницького завдання студента. Технологія проектування має великі можливості для формування усіх перерахованих вище умінь студентів, а також для набуття ними ще у ВНЗ навичок творчої проектувальної діяльності. Наведемо зразки пропонованих студентам проектних завдань:

1. Розробити варіанти проведення спільних занять старших дошкільників і молодших школярів у навчально-виховному комплексі «дошкільний заклад - початкова школа».

2. Розробити проект спільної діяльності вчителя і вихователя в різних формах організації виховної діяльності в НВК, визначити зміст цієї діяльності на засадах інноваційних технологій.

3. Розробити проект спільної громадянської акції для різновікового колективу дітей дошкільного навчального закладу.

4. Розробити алгоритм проектування організації різних видів діяльності вихователем на засадах інноваційних технологій.

Під час виконання різноманітних проектів студенти вчаться виконувати різні види проектування: виявлення і аналіз проблеми як результат суперечності між необхідною інноваційною діяльністю педагога та тією, що склалась в практиці НВК; пошук новітніх підходів для створення проектів; розроблення програми моделювання діяльності учасників проекту для реалізації інноваційних ідей у навчально-виховному процесі НВК; планування як поетапне розроблення алгоритму взаємопов'язаних дій учасників проекту; конструювання інноваційної практики в комплексі через реалізацію програми і планів проекту; рефлексія оформлення результатів реалізації проекту; усвідомлення студентами результатів власної діяльності в процесі реалізації проекту, співвіднесення досягнутих результатів із критеріями нормативної діяльності педагогів.

Зазначимо, що використання технології проектів дозволяє інтегрувати знання, вміння $\mathrm{i}$ навички студентів 3 педагогіки, психології та різних методик, учить моделювати 
інноваційну діяльність дошкільного педагога, формує педагогічне мислення, демократичний стиль майбутньої професійної діяльності.

Аналіз діяльності студентів під час різних видів практики засвідчує, що ця технологія вчить успішно відбирати потрібну інформацію 3 різних першоджерел, інтегрувати отримані дані задля досягнення поставлених завдань і шукати інноваційні способи їх використання. Практика засвідчує, що використання цієї технології стимулює інтерес студентів до інноваційної діяльності, переконує в необхідності набуття навичок проектування і моделювання нових підходів до організації навчально-виховного процесу в дошкільних навчальних закладах.

Отже, констатуємо, що метод проектів ефективно впливає на удосконалення професійної підготовки майбутніх вихователів дошкільної освіти, стимулює інтерес студентів до інноваційної діяльності. Викладачі ВНЗ повинні стимулювати студентів до інноваційного пошуку, самостійного педагогічного мислення, самоосвіти та самовдосконалення протягом усього життя. Метод проектів $\epsilon$ одним із сучасних ефективних методів, використовуваний у сучасній професійній освіті. У його основі лежить особистісно зорієнтований підхід до навчання й виховання дітей і молоді. Він розвиває пізнавальний інтерес студентів до реалізації різних галузей знань в освітніх закладах, формує навички співпраці, дослідницький пошук педагогів. Важлива роль під час використання такого методу належить розвитку творчої уяви студентів і подолання їхньої психологічної інерції. Зазначене визначає необхідність подальшого пошуку шляхів розв'язання цієї проблеми.

\section{Література}

1. Біла книга національної освіти України / Т. Ф. Алексєєнко, В. М. Аніщенко, Г. О. Балл [та ін.]; за заг. ред. акд. В.Д. Кременя; НАПН України - К.: Інформ. системи, 2010. - 342 с. 2. Інноваційні педагогічні технології. - К.: ІЗМН, 2004. - 546 с. 3. Метод проектов в университетском образовании: [сб. науч.-метод. статей]. - Вип. 6. / [под общ. ред. М. А. Гусаковского]. - Минск : БГУ, 2008. - 244 с. 4. Юсуфбекова Н. Общие основы педагогической инноватики: опыт разработки теории инновационных процессов в образовании / Н. Юсуфбекова. - М., 1991. - 41 с.

\section{ФОРМУВАННЯ ПРОФЕСІЙНОГО СВІТОГЛЯДУ МАЙБУТНЬОГО ВИКЛАДАЧА ЗАРУБІЖНОЇ ЛІТЕРАТУРИ ЯК МЕТА І СОЩАЛЬНО ЗНАЧУЩИЙ РЕЗУЛЬТАТ ЙОГО ФАХОВОЇ ПІДГОТОВКИ У ВИЩОМУ НАВЧАЛЬНОМУ ЗАКЛАДІ}

Романець В. М. Формування професійного світогляду майбутнього викладача зарубіжної літератури як мета і соціально значущий результат його фахової підготовки у вищому навчальному закладі.

У статті подано результати теоретико-експериментальної роботи з формування професійного світогляду майбутнього викладача зарубіжної літератури в умовах євроінтеграції та глобалізації освітньо-наукового простору вищої школи. Особливу увагу приділено висвітленню концептуальних засад дослідження.

Ключові слова: викладач зарубіжної літератури, професійна підготовка майбутніх викладачів зарубіжної літератури, формування професійного світогляду.

Романец В. М. Формирование профессионального мировоззрения будущего преподавателя зарубежной литературы как цель и социально значимый результат его подготовки в вузе.

В статье освещены результаты теоретико-экспериментальной работы по формированию профессионального мировоззрения будущего преподавателя зарубежной литературы в условиях 